\section{Resenha do livro}

\section{"Atlas of Temporal Bone Surgery" de Tuncay Ulug.}

O livro Atlas of Temporal Bone Surgery, de Tuncay Ulug, Thieme, 1a . edição, 2010, em inglês, contém 203 páginas ricamente ilustradas que ajudam a compreender a anatomia e técnicas cirúrgicas do osso temporal.

O livro aborda de forma didática cirurgias de orelha externa, média e interna, com ilustrações detalhadas passo a passo que servem de referência não só para residentes como para cirurgiões experientes que desejam ampliar e reciclar seus conhecimentos.

Os primeiros capítulos são dedicados a aspectos gerais, comuns a todas as cirurgias otológicas. Incluindo o manejo adequado dos instrumentais cirúrgicos, especialmente as brocas. O autor sugere o tamanho e tipo de brocas mais adequados para cada passo cirúrgico e a forma adequada de se realizar hemostasia. Trata-se de um livro prático e objetivo, tornando o estudo agradável.

Os demais capítulos são dedicados cada um a uma cirurgia em específico. Em cada um deles discute-se inicialmente a indicação do procedimento, seguido do detalhamento por passos. Em cada passo dispõe-se de uma foto de osso temporal com a indicação das estruturas anatômicas e também do instrumental utilizado para sua realização.

Há descrição de cirurgias menos complexas como as miringoplastias até acessos neurotológicos para o cirurgião experiente. Em todos os procedimentos descritos há uma preocupação na definição e embasamento teórico relacionadoà prática cirúrgica.

O livro inclui ainda cinco capítulos com técnicas cirúrgicas desenvolvidas pelo próprio autor, descritas de forma esquemática que podem dar uma outra visão ao leitor.

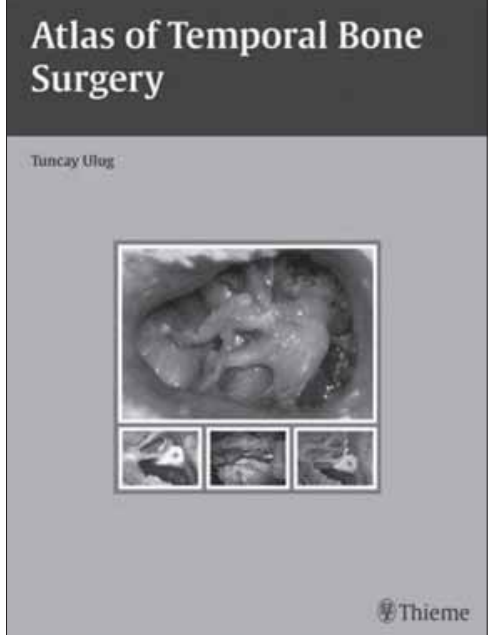

Quanto às limitações da obra, o que mais nos chamou a atenção foi o uso de peças anatômicas para ilustração, não se utilizou material cirúrgico, isso compromete , de certa forma, a coloração das peças, especialmente onde há vasos e nervos.Entretanto, não há prejuízo do detalhamento dos procedimentos.

Em resumo, trata-se de uma obra interessante para aqueles lidam com cirurgia otológica e neurotológica. Graças à abrangência dos temas pode ser utilizada por profissionais em diferentes níveis de formação.

Mariana Hausen Pinna

Médica Assistente do Grupo de Otologia do HCFMUSP Especialista em Cirurgia Otológica e da Base Lateral do Crânio 